\title{
Astronomy for teachers in Mexico
}

\author{
Julieta Fierro ${ }^{1}$ \\ ${ }^{1}$ Instituto de Astronomía, UNAM, Mexico City, Mexico \\ email: julieta@astroscu.unam.mx
}

\begin{abstract}
In this paper I shall present ways in which professional astronomers in developing nations can aid basic education by using a few things that have been done in Mexico.

Recently the compulsory education in Mexico was increased from 6 to 12 years. An optional subject on astronomy was included in high school; so there are several ways in which one can contribute to the national education system.

I shall give a practical example on ways to teach and mention the importance of magazines and books dedicated to teachers. I will also address the way we have implemented brief courses for educators and organized conferences for science teachers.

It is important to emphasize that we must find ways to train people in a more effective way.
\end{abstract}

Keywords. Astronomy teaching, Mexico

\section{How to teach}

There is educational research going on in several nations, with many interesting results, unfortunately it is difficult for practical information to get to teachers. I encourage researchers to post their educational materials on the World Wide Web and to write for educators.

In Mexico we have several magazines for teachers, for instance "El Correo del Maestro" includes astronomy articles and edits 17000 copies, which is a large number for a developing nation and a small one compared to the amount of elementary school teachers we have: over a million.

I believe we can extract from other species the basics of good education by observing how primates teach their young. If we analyse how a mother aids her child to use a stick to break nuts we can observe how she uses the following steps:

(a) She exposes him to interesting surroundings (she takes him to a site where other large apes are using tools to break nuts).

(b) She lets him experiment on his own (she watches while he tries to break nuts with an improper tool, does not succeed and even gets slightly injured).

(c) She acts at the precise moment, when the infant is about to give up, and teaches him how to grab the correct tool.

(d) She allows her child to practise till he masters nut breaking (the mother follows closely and only helps in case of necessity). In other words, the student must learn on his own and the teacher should go way beyond lecturing, set an example and become a facilitator.

These are the same items can be used for good teaching: Expose, experiment, facilitate, practice and succeed. We should of course add another step: creation. We want our students to go beyond current knowledge. Creation occurs when items that seemed disconnected are joined. For instance, painters or composers put together colour, shapes, sounds and rhythms in ways nobody has done before. So we must expose our students to an interesting and varied set of ideas and allow them to ponder about them and give challenging assignments. 


\section{Pre-school in Mexico}

Pre-school in Mexico has recently been increased from one to three years. This means many new teachers must be trained. In Mexico education in mainly state run.

Luckily a group or elementary school educators contacted me with a list of 600 science questions that students had asked and they did not how to answer. So a group of educators answered them and five books were published with the answers and related topics. The group of original teachers sold the books personally; to make sure they got to the teachers that were interested in them.

Pre schoolteachers have several problems in answering science topics. Twenty one per cent of households have only one provider, women. So mothers have less time to teach their children how to talk and teachers are assuming this responsibility. Instructors have to understand science questions in a poor language, translate in a way a scientist can understand it, and translate the answer back in a way the child can comprehend it.

In order to contribute to the national effort I wrote a wordbook. The words are placed in alphabetical order, each has to do with science, I tried to make them difficult to pronounce, for instance they have three syllables or sounds such as "rui" that are hard for small children to pronounce. Each page has the word, its definition and a small sentence where it is used, written by a poet (Alberto Vital). The book is to aid both mothers and teachers: a word a day keeps poor learning skills away. As we all know words are necessary to build ideas.

I also wrote an astronomy book in small format. Then I realized teachers wanted large format books, so the children could see the pictures. So large format books were printed for teachers and small format books for students. Experience showed that students also wanted large format books. So I began a series of science books for pre school students in large format. The topics include light, sound and time, all with an astronomical component. I am preparing one on water and will continue with the sky.

\section{Middle school}

Three years of middle school, ages 12 to 15 have been added to compulsory education in Mexico.

I believe subjects that are meaningful for children are those that should be taught.

Part of the present curricula seems to me extremely boring it includes little astronomy in spite of it being attractive for both teachers and students.

I have written several books for that age level that has been included in the classroom library. This library is furnished with books chosen by the teachers. They can select about ten books every year. One of the books I wrote was on scatology to make a point about reading; students read if they are interested. Students read it in groups, laugh and talk about the book, that are qualities all books should have. This book has been on the top place in the list of most bought books on Mexico's most popular bookstore.

I am presently writing more books for this age level. Since Astronomy has been excluded in wont be taught in a boring way, due to its multidisciplinary nature it is ideal for informal reading.

\section{High school teacher training}

For many years there was an optional course on positional astronomy in the geography department of Mexican high schools. It was changed to a general astronomy course in the physics department. 
A teachers' 180-hour-long course was designed for their training. At first professional astronomers lectured, and little by little the high school teachers have learned to train each other. Some of them have written materials and placed them with sets of images for lectures on line.

I believe on learns when one teaches, and having high school instructors train themselves have given them more confidence in what they teach.

\section{Symposia}

The Mexican Academy for Science Teachers is an association whose members include all level teachers, from Pre School to graduate. Its main activity is a bi-annual conference where about 1500 teachers attend. Lectures, workshops, demonstrations, books on astronomy are always present. (www.ampcn.org.mx)

In developing nations such meetings are hard to organize, teachers are not used to presenting posters, it is not always easy to convince authorities to allow them and sponsor their participation and there is not a tradition of fund raising.

Nevertheless teachers benefit immensely by going to meetings. Multilevel bilingual teachers in remote areas can share experiences with their pears. Teachers feel proud of what they are achieving when they compare their work with the efforts made elsewhere. They can purchase books, magazines and teaching materials.

\section{Books}

I believe the importance of books cannot be over stated. Not only books should be edited but available.

Mexico has done three things to promote reading:

(a) Small libraries in school rooms

(b) Book fares

(c) A new major library that includes scholars on the board.

Classroom libraries hold books that have been selected by teachers from a group of 700. They can pick 10 per year. The 700 titles comes from a previous selection among the 13000 that are printed in Spanish in different countries and are presented to the selection committee by the editors. Some examples of books in Spanish by this author that are available in schools are listed as references at the end of this paper.

A new large library was built in Mexico City in a section that has little cultural activities. There are several scholars on the board that not only have contributed by suggesting titles but to other activities such as workshops, lectures, use of the www, etc.

\section{Conclusion}

In developing nations good quality science education for a large portion of the population is needed. Curricula reforms are only a very small portion of what is needed. Children must be well nourished and healthy in order to learn.

In Mexico astronomy is not taught as such at any level, due to its appeal written materials must be available for teachers and students.

If one wants to improve the quality of education one must take time to work with teachers in order to understand their needs and difficulties. 


\section{References}

Delgado, H. and Fierro, J., Volcanes y Temblores en México. Editorial SITESA, 2004

Domínguez, H. and Fierro, J., Albert Einstein: Un cientfico de nuestro tiempo. ISBN 970-321108-9, Editorial Lectorum, 2005

Domínguez, H. and Fierro, J., La luz de las estrellas Correo del Maestro, ediciones La Vasija, 2006-06-22 ISBN 9707560959

Domínguez, H. and Fierro, J., Galileo La Vasija, en Prensa, 2007

Fierro, J. and Vital, A., Palabras para conocer el mundo, 2006, Editorial Santillana.

Fierro, J., Lo grandioso del sonido, Gran paseo por la ciencia, Editorial Nuevo México ISBN 970-677-180-8, 2006

Fierro, J., Lo grandioso de la luz, Gran paseo por la ciencia, Editorial Nuevo México ISBN 970-677-181-6, 2006

Fierro, J., Lo grandioso del tiempo, Gran paseo por la ciencia, Editorial Nuevo México ISBN 970-677-179-4, 2006

Fierro, J. and Sánchez, V.A. Cartas Astrales, Un romance cientfico del tercer tipo Editorial Alfaguara 2006 ISBN 968-19-1175-X

Fierro, J., El Sol, la Luna y las Estrellas DGDC, Colección Ciencia para Maestros, ISBN 97032-1108-9, 2004

Fierro, J., La astronoma de México, ISBN 968-5270-55-4 Lectorum, 2001

Spadaccini, J., Fierro, J., Paglierani, R., Hawkins, I. and Cline, E.U. Úuchbenil le K'inó, Tradiciones del Sol, Traditions of the Sun Libro trilinge: Maya, Español, Inglés NASA, 2006

Tonda, J. and Fierro, J., El libro de las cochinadas, Ilustraciones de José Luis Perujo ADN Editores, 2005

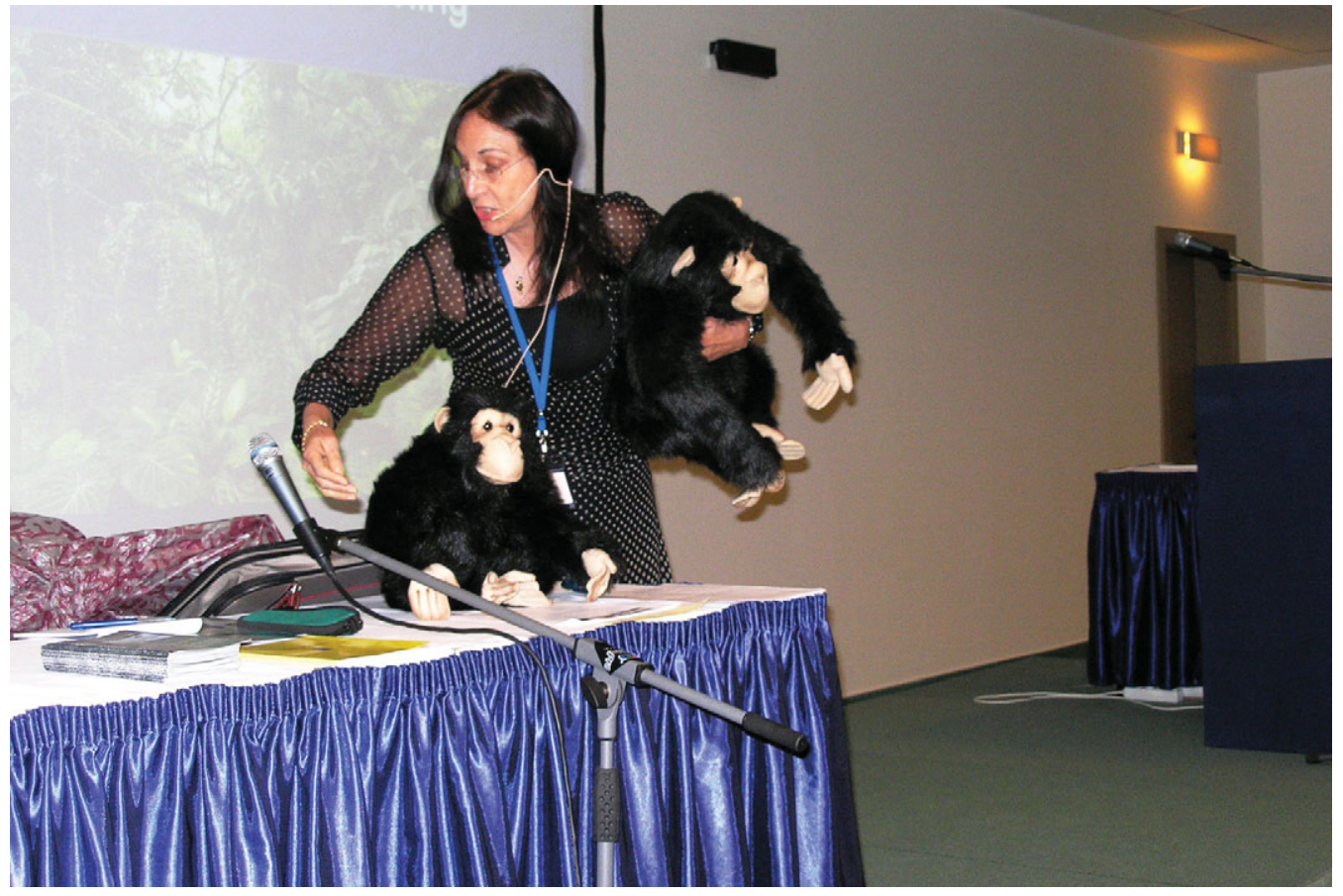

Julieta Fierro and her monkey tricks 